專門医症例報告

$$
\text { ミリング・テクニックを用いた補綴処置の一症例 }
$$

片瀬 志穂

\title{
A Case Report of Prosthetic Treatment with Milling Techniques
}

\author{
Shiho Katase
}

抄 録

症例の概要：患者は 51 歳女性。下顎左側小臼歯部辺縁歯肉の違和感，下顎左側大臼歯部欠損による咀嚼 困難を主訴に来院.歯周治療後, ミリング・テクニックを用いた部分床義歯を装着し咬合の回復を図った. 考察：装着後 4 年経過時に，支台歯の歯根破折が認められた。これは，高い機能力が発揮されたがゆえ の弊害であったと考察される。しかし，QOLに関する客観的な評価は良好な結果を示しており，本症例 における治療計画は妥当であったと判断される。

結論：片側性に大臼歯の喪失した症例に対して，機能時の義歯の動きを抑制する目的でミリング・テクニ ックを用いたことは，咀嚼機能を回復し，QOL の向上にとって有効であった.

和文キーワード

リジットサポート，ミリング・テクニック，遊離端欠損，咀嚼障害

\section{ABSTRACT}

Patient: A 51-year-old female presented with the chief complaint being discomfort at the marginal gingiva in relation to the left mandibular premolar region and difficulty in mastication resulting from missing teeth in the left mandibular molars. After treating the gingiva around the remaining teeth, we placed a partial denture using the milling technique to restore the occlusion.

Discussion: Four years after the partial denture was placed, root fracture of the abutment tooth was observed. The damage may have occurred because of the high functional force exerted on this tooth. However, an objective evaluation indicated positive results with respect to quality of life, and we concluded that the treatment plan had been appropriate for this patient.

Conclusion: Because the patient had lost a molar on one side, the milling technique employed to suppress movement of the denture when functioning was effective in restoring masticatory function and improving quality of life.

\section{Key words}

rigid support, milling technique, free-end defect, masticatory dysfunction 


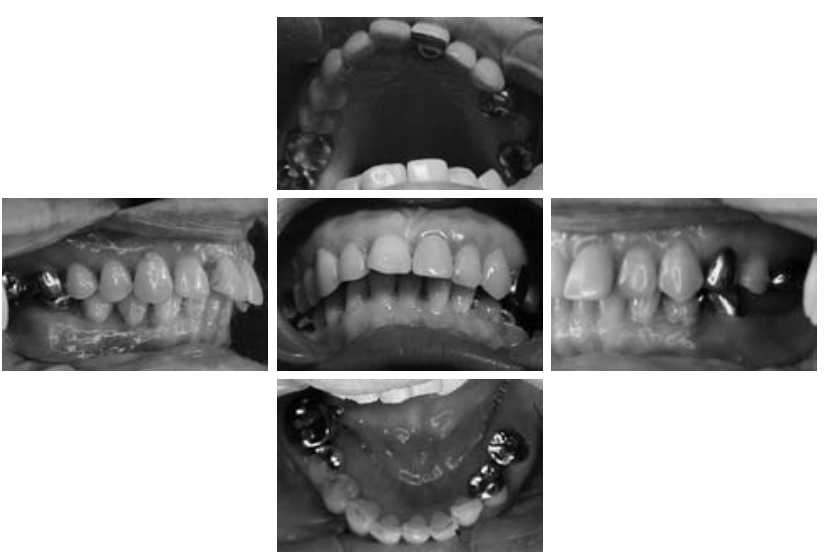

図 1 Intraoral view at the first visit 初診時口腔内写真

表 1 Examination of periodontal status at the first visit 初診時の歯周基本検査

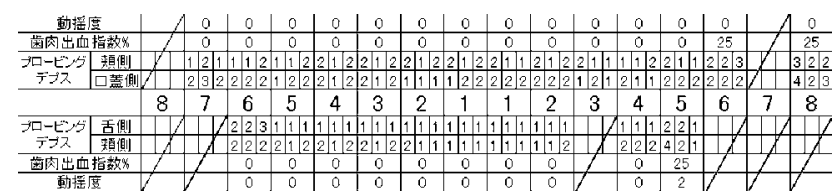

\section{I 緒訔}

歯科補綴の目的は，失われた口腔領域の形態，機能の 回復と改善，顎口腔系の形態や機能を健全な状態に保全 することである ${ }^{1,2)}$. 特に部分床義歯において，この目 的を達成するためには，(1)義歯の動摇の最小化，(2)予防 歯学的配慮，3破損の防止，の設計原則が重要であると 考えられている ${ }^{1-3)}$.

本症例では，片側性の遊離端欠損に対して，「義歯の 動摇の最小化」を得るため, 残存歯と義歯床の一体化 （リジットサポート）に着目し ${ }^{2,3)}$ ，支持と把持を中心 としたミリング・テクニックを用いて補綴処置を行つた 結果，8 年間の予後を得たので報告する.

\section{II、症例の概要}

患者 : 51 歳 (初診時)，女性.

初診日：2002 年 7 月 8 日。

主訴：左側で噛めない，左下の歯肉に違和感がある。

既往歴：全身的，歯科的な特記事項なし.

現病歴：1997 年に67 の抜去を行ったが，欠損部は 放置されていた. 数力月前から 45 付近の歯肉の違和 感を覚え, 同部の精査と欠損部の治療を希望し来院し た。

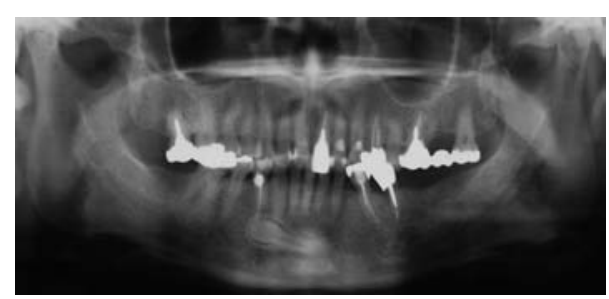

図 2 Panoramic radiograph at the first visit 初診時パノラマ X 線写真

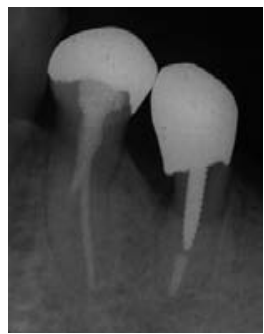

図 3 Dental radiographs at the first visit 初診時デンタル X 線写真

現症：口腔内所見（図 1）初診時，全顎的に歯肉の軽 度発赤と腫脹が認められた。 4 は全周にわたりポケッ ト 1〜2 mm で動摇度は認められなかった。しかし， 5 は近心部のポケットは $4 \mathrm{~mm}$, 動摇度 2 度を示し（表 1), 側方誘導時において強い干渉か認められた。また, $\longdiv { 6 7 }$ 部の欠損は放置されており，欠損部の咬合支持を 担うために 5 の負担過重が生じている可能性が考えら れた. 7 欠損については (6) 7 8のブリッジが装着され ていたが，8の挺出が認められ，67部の補綴間隙が 不足していた。7損については自覚なく放置されて おり，76にはは連結された全部鋳造冠が装着されてい た。 また， 3 は欠損していたが歯列不正は認められな かった。 欠損状態は Kennedy 分類 I 級, Eichner 分 類 B-1 型であった。

検査結果 : X 線所見 (図 2) パノラマ X 線写真上で, 全顎的に軽度の水平的な歯槽骨吸収が認められた。 5 についてはデンタル X 線上で，近心部に垂直性の骨吸 収が認められた（図 3)。厲が下顎前歯部の根尖付近に 埋伏していた。 8 の遠心咬頭は下顎歯槽骨に近接して おり，近遠心的に水平性の骨吸収か認められた。

診断：全顎的な単純性歯肉炎，67 欠損による咀嚼 障害, 5 の咬合性外傷, 慢性歯周炎, 18 の慢性歯周炎.

\section{III，治療内容と経過}

\section{1. 治療方針および計画}

まず全顎的な歯周治療を行い，次いで，67 欠損に 


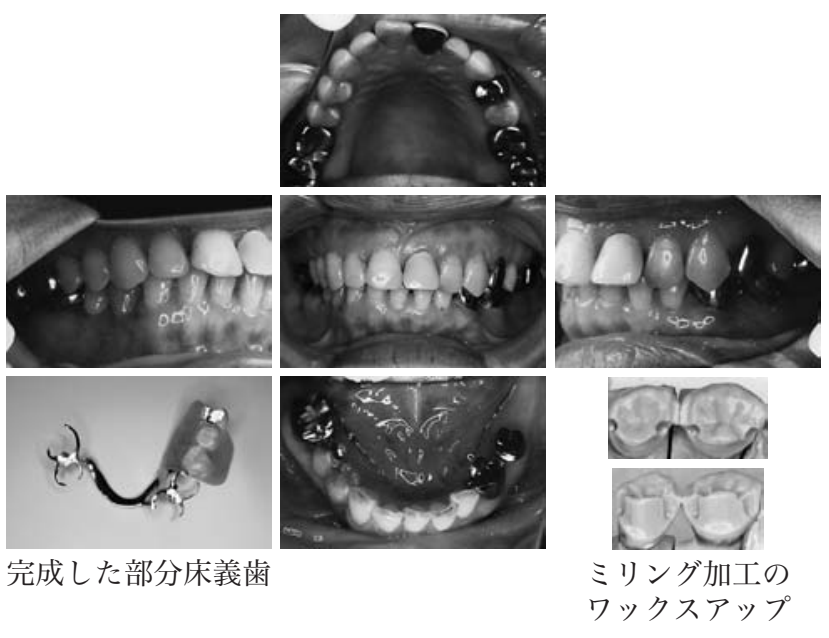

図 4 Intraoral view during the treatment 治療中口腔内写真

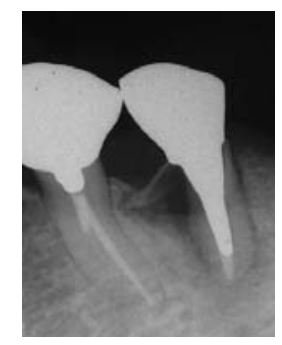

図 5 Dental radiographs during the treatment 治療中デンタル X 線写真

対しては欠損補綴治療を行うこととした。術前に検査結 果，診断と今後の治療方針について十分な説明を行い, 治療の同意を得た。特に, 67 欠損部の治療について は，インプラントや部分床義歯を用いた補経治療，およ び放置した場合のリスクなどの説明を行い，部分床義歯 を選択した。また，7㐸損については，補綴処置を行 わず経過観察とした。

\section{2. 処置内容}

治療計画に基づき歯周治療から開始した。 67 欠損 部については，機能時の義歯の動摇を最小限にするため に，ミリング・テクニック ${ }^{2,3)}$ を用いた部分床義歯を製 作することとした。 45 には，舌側を含め義歯の着脱 方向と平行にミリング加工した全部鋳造冠（金銀パラジ ウム合金製）を装着し，これに適合する直接支台装置を 施した部分床義歯(コバルトクロム合金製)を製作した。 65 には間接支台装置を設定した（図 4，5)。また，8 の対合歯部分には, 人工歯の排列スペースがないため, メタルの義歯床で直接咬合させ，床の破折を予防した。
表 2 Examination of periodontal status during $t$ the treatment

治療中の歯周基本検査
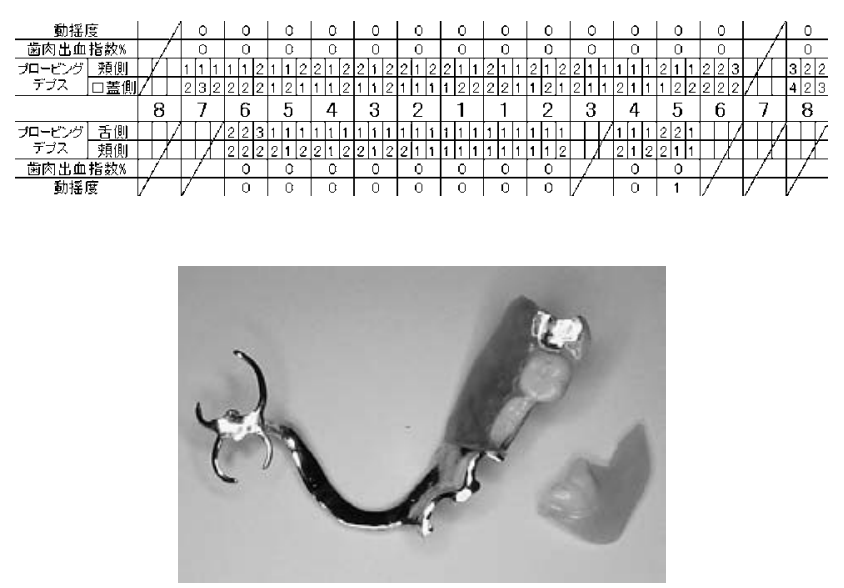

図 6 Fractured removable partial denture 破折した部分床義歯

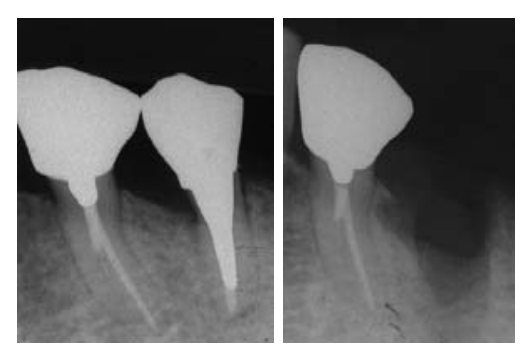

図 7 Dental radiographs of $\overline{5}$ with root fractured (before and after extraction)

「5の歯根破折時におけるデンタルX 線写真（抜去 前・後)

\section{3. 術後の経過}

装着直後から経過観察を 2〜3 カ月ごとに行っていた (表 2). 装着後 1 年経過して患者の使用上の不注意に より, 義歯の 6 人工歯部と㚘側のレジン床部が破損し たため修理を行った（図 6)。再び経過観察を続けてい たが，装着後 4 年経過して厌の歯根破折が認められた ため同歯を抜去し（図 7), 増歯修理とリライニングを 行った。 その後, 現在 (義歯装着後 7 年目・ 5 抜去か ら 3 年目) に至るまでは良好な予後を得ている（表 3 , 図 8).

\section{4. 術後の機能評価}

OHIP-J を用いた ${ }^{4)}$ 口腔関連 QOL に関するアンケー 卜調査では，術前は 66 点であったが，義歯装着後 3 年目には 49 点, 義歯装着後 7 年目には 44 点となり, 良好な評価結果が得られた。また，グミゼリー（大阪大 学開発, UHA 味覚糖 $)^{5)}$ を用いた咀嚼機能検査において 

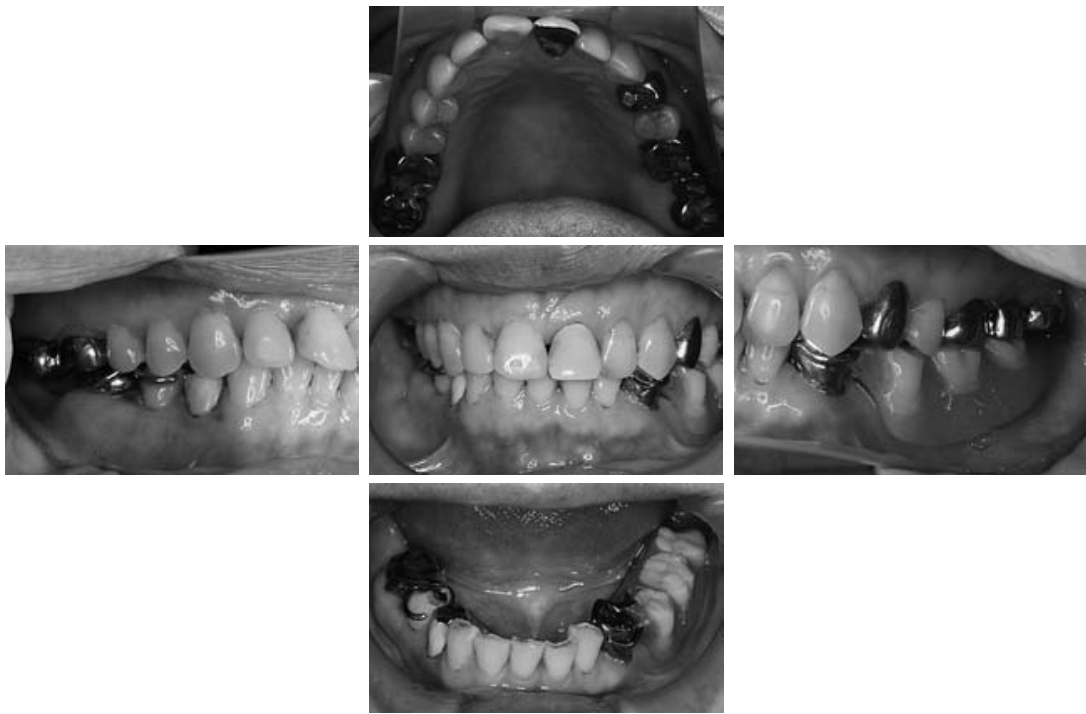

図 8 Intraoral view at 7 years after prosthetic treatment 補綴治療終了 7 年後の口腔内写真

表 3 Examination of periodontal status at 7 years after prosthetic treatment 補綴治療終了 7 年後の歯周基本検査

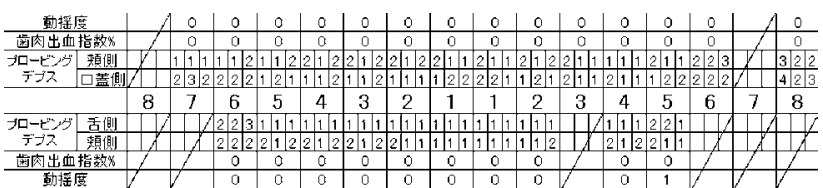

も，術前は 3,298.8 mm² (286 ml/dl) であったが, 義歯装着後 3 年目には 4,000.1 mm² (340 ml/dl), 装 着後 7 年目には $4,104.0 \mathrm{~mm}^{2}(348 \mathrm{ml} / \mathrm{dl})$ と, 高い 咀嚼能率が確認された。

\section{IV. 考察}

本症例では，下顎左側大妇歯欠損に伴う咬合支持の喪 失を，可及的に動きの少ない部分床義歯を用いて回復す ることが焦点であった，機能時における義歯の動きを抑 制することで，安定した咀嚼運動が営まれ，支台歯の二 次固定効果 ${ }^{2,3)}$ も得られると判断した.

装着後 4 年経過時に支台歯の歯根破折が認められた が,これは, 高い機能力が発揮されたがゆえの弊害であつ たと考察される。しかし，QOL に関する客観的な評価 は良好な結果を示しており，本症例における治療計画は 妥当であったと判断される。

\section{V. 結 論}

片側性に大臼歯の喪失した症例に対して，機能時の義 歯の動きを抑制する目的でミリング・テクニックを用い たことは，咀嚼機能を回復し，QOL の向上にとって有 効であった。

\section{文献}

1）後藤忠正．クラスピング．東京 : 医歯薬出版；1990，110.

2）小野寺保夫. ミリングの基礎知識と実践. 東京：クイン テッセンス出版；2001，65-80.

3）後藤忠正. パーシャルデンチャーのプランニング \&デザ イニング. 東京 : 医歯薬出版 ; 1995，15-42.

4) Yamazaki M, Inukai M, Baba K, John MT. Japanese version of the oral health impact profile (OHIP-J). J Oral Rehabil 2007; 34: 159-168.

5) Ikebe K, Morii K, Matsuda K, Hazeyama T, Nokubi T. Reproducibility and accuracy in measuring masticatory performance using test gummy jelly. Prosthodont Res Pract 2005; 4: 9-15.

著者連絡先：片瀬 志穂

干399-0781 長野県塩尻市広丘郷原 1780

Tel: 0263-51-2056

Fax: 0263-51-2056

E-mail:a_shiho215@po.mdu.ac.jp 